\title{
Diversity Analysis of Selected Solanum Species in Sri Lanka using Molecular and Morphological Descriptors
}

\author{
R.M.N. Dissanayake, N.D.U.S. Nakandala ${ }^{1}$, P.W.I. Nawanjana ${ }^{1}$, R.M.S.K. Rathnayake ${ }^{1}$, \\ H.M.T.N. Senavirathna ${ }^{1}$, R.W.K.M. Senevirathne ${ }^{1}$, W.M.D.A. Wijesundara ${ }^{1}$, \\ L.T. Ranaweera ${ }^{1}$, O.W.S.H. Ariyathilaka ${ }^{2}$, C.K. Weebadde ${ }^{3}$ and S.D.S.S. Sooriyapathirana ${ }^{1 *}$
}

\author{
Postgraduate Institute of Science \\ University of Peradeniya \\ Sri Lanka
}

\begin{abstract}
The family Solanaceae is composed of a broad list of species, which includes both commercial and wild accessions with enormous medicinal importance. The published phylogenies on Sri Lankan wild and naturalized Solanum spp. confers that S. hispidum, and S. torvum are sister species. However, this has not been proved using multiple barcoding markers. Moreover, S. torvum, an underutilized crop is expected to contain multiple varieties. However, varietal descriptions using morphological and DNA markers have not been done so far. Therefore, our study was aimed at accurate identification of four Solanum spp. found in Sri Lanka (S. torvum 'Bindu' and landraces S. hispidum and S. pubescens) using chloroplast marker based DNA barcoding combined with a morphological description. We used 29 quantitative and 22 qualitative parameters, comprised of vegetative and reproductive traits along with eight DNA barcoding markers. We sequenced rbcL and trnL-F to check the DNA polymorphisms. According to the combined morphological analysis of reproductive and vegetative parameters, the four species clustered separately. There were no separation observed between S. torvum and S. hispidum. Solanum pubescens diverged out and cladded with old world nightshades in molecular analysis. These results are in line with published literature and validates that trnL-trnF could be used as a potential marker to carry out a combined DNA barcoding analysis with matK. However, trnL-trnF could not be used to discriminate between $S$. torvum and S. hispidum species.
\end{abstract}

Keywords: DNA barcoding, solanum morphological and molecular assessments, conservation, wild relatives

\section{INTRODUCTION}

The genus Solanum belongs to the tribe Solaneae, subfamily Solanoideae, and family Solanaceae which is comprised of species with substantial economic importance worldwide (Mace et al., 1999; Seguí-Simarro, 2016). The members of Solanaceae species found in the tropics are generally considered as annual herbs while those in the temperate regions are annuals. They grow as a bush up to a height $8 \mathrm{f}^{\mathrm{a}} \mathrm{0} .5-2.5 \mathrm{~m}$. The fruits produced may vary from a small number to several (Rubatzky and Yamaguchi, 1997).

\footnotetext{
1 Department of Molecular Biology and Biotechnology, Faculty of Science, University of Peradeniya, Sri Lanka

2 Regional Agriculture Research and Development Center, Bandarawela, Sri Lanka

3 Department of Plant, Soil and Microbial Sciences, Michigan State University, East Lansing, Michigan, USA

* Corresponding author: sunethuop@gmail.com
} 
The members of the family Solanaceae are well known for the remarkable medicinal properties found in leaves, fruits and roots (Jeyakumar et al., 2016). The fruits of Solanum torvum Swartz are used as a cure for cough, liver and spleen disorders (Siemonsma and Piluek, 1994). It has further been discovered to have tranquilizing and diuretic properties and a broad array of antibacterial and antifungal effects on human and animal pathogens (Gousset et al., 2005; Chah et al., 2000; Abas et al., 2006). The phenolic compound present in the fruits of S. torvum is used as an anti-diabetagenic and antioxidant (Gandhi et al., 2011; Loganayaki et al., 2010). The leaves are utilized as a stabilizing agent of blood flow. Tonics and blood cell regeneration agents are prepared from mature fruits and they are also employed for the curing pains and skin diseases (Kala, 2005). Solanum hispidum has been evaluated for the anti-fungal activity due to the presence of a novel spirostanol and several other saponins (González et al., 2004; Chakravarty et al., 1982).

The species of Solanaceae grown in Sri Lanka include. S. melongina, S. torvum-Bindu ('Thibbatu)', S. torvum-Landrace ('Thibbatu'), S. hispidum ('Gonabatu') and S. pubescens ('Walthibbatu'). Majority of the research conducted in Sri Lanka are focused on 'wambatu' or $S$. melongena eggplant which thrives well in the rain-fed and minimum irrigation facilities due to great stress resilience of the plant (DOA, 2018). Solanum melongena is cultivated as a commercial crop in Sri Lanka. However, the ability of the varieties of eggplant to resist biotic stress such as bacterial and fungal and other nematode and insect attacks is poor. Thus, the development of resistance by identification of resistant genes from the wild relatives is highly recommended (Collonnier et al., 2001). Certain wild relatives of $S$. melongena such as $S$. torvum harbors a consortium of resistant genes which can be readily employed in breeding programmes. S. torvum has been identified as resistant to wilt diseases and certain other pests such as nematodes. The resistance has been transferred to the commercial varieties of Solanum spp. through various breeding programs (Jarl et al., 1999). Interspecific hybridization has been carried out between commercial eggplant cultivars and S. torvum (Collonnier et al., 2003; Clain et al., 2004; Gousset et al., 2005). However, the precise identification of species/varieties play a crucial role in subsequent breeding protocols as most of the wild relatives possess undesirable traits which can be easily transferred to the genomes of improved cultivars when subjected to breeding (Prohens et al., 2017).

DNA barcoding can be identified as a key and robust strategy in successful species identification (Group et al., 2009). Several research studies have been carried worldwide for successful identification of the Solanum spp. especially to detect the adulterations when used as medicinal plants (Techen et al., 2014). Solanum species have also been used in DNA barcoding projects carried out for conservation of local biodiversity in certain other regions of the world (Boessenkool et al., 2014). However, studies have not yet been carried out for the varieties/species of the genus Solanum found in Sri Lanka especially for the wild relatives such as $S$. torvum. Thus, the present study was conducted to accurately identify the varieties of Solanum spp. found in Sri Lanka for the future use of the species in wide hybridization protocols and conservation of the wild germplasm of Solanum spp.

\section{METHODOLOGY}

\section{Collection of the plant material}

The study was carried out with four species of wild relatives of brinjal (Solanum melongena) (S. torvum 1: 'Thibbatu' variety Bindu recommended by the Department of Agriculture 
(DOA), Sri Lanka; S. torvum 2: landrace of 'Thibbatu'; S. hispidum: 'Gonabatu'; S. pubescens: 'Walthibbatu'). Breeder seeds of $S$. torvum 1 were sourced from the Regional Agriculture Research and Development Center, Aralaganwela, Sri Lanka and S. torvum 2 from a farmer in Girandurukotte. Solanum hispidum was collected from roadsides at Haggala, Nuwara Eliya, while $S$. pubescens were collected from roadsides at Baragama, Hambanthota.

\section{Establishment of plant material}

The nursery bed was prepared by using soil and coir dust (1:1), treated with Topspin and was kept for 24 hours for disinfection. Seeds were soaked in pure water and was allowed to germinate. Pits of $0.09 \mathrm{~cm}^{2}$ dimensions were prepared on $10 \mathrm{~m}^{2}$ plots with a space of $1 \mathrm{~m}$ between rows and $2 \mathrm{~m}$ between plants. Plots were maintained at the open fields of the Regional Agriculture Research and Development Centre, Bandarawela (IU3a-average annual rainfall of $>1900 \mathrm{~mm}$, maximum average temperature of $27^{\circ} \mathrm{C}$, minimum average temperature of $14^{\circ} \mathrm{C}$ ), Welimada, and farmer fields at Masnawatta and Mirahawatta, Welimada (U3d-Average annual rainfall of $>1300 \mathrm{~mm}$, maximum average temperature of $28^{\circ} \mathrm{C}$, minimum average temperature of $15{ }^{\circ} \mathrm{C}$ ) (Reddish yellow Podsolic soil in both locations). The pits were filled with a mixture of decomposed cattle manure and topsoil in 1:1 ratio and the basal fertilizer was added according to the recommendation of the Department of Agriculture, Sri Lanka. Four weeks old seedlings were transplanted according to an incomplete block design (IBD) with four genotypes, and five blocks in Bandarawela and three blocks in Welimada sites.

Three individuals per each genotype in each block were assessed for 29 quantitative and 22 qualitative (vegetative and reproductive) parameters. Vegetative parameters including cotyledon length $(\mathrm{CL})$, cotyledon width $(\mathrm{CW})$, cotyledon length / cotyledon width ratio $(\mathrm{CL} / \mathrm{CW})$, leaf blade length (LBL), leaf blade width (LBW), leaf petiole length (LPL), leaf blade tip angle (LBTA), number of leaf prickles (NLP), plant height (PlH), mean canopy width $(\mathrm{MCW})$, number of branches per plant $(\mathrm{NB})$ were measured to describe the morphological variability of leaves and stems. The reproductive traits at flowering stage; number of flowers per inflorescence (NFPI), flower diameter (FD), petal length (PL), petal width (PW), length of stigma exerted (LSE), length of anther (AL), width of anther (AW), days to flowering (DF) were measured. Similarly, at the harvesting stage, the fruit parameters including fruit length (FL), fruit breadth (FB), fruit length/fruit breadth ratio (FL/FB), length of stalk (LS), thickness of stalk (TS), individual fruit weight (IFW), 100 fruit weight (HFW), seed diameter (SD), and 100 seed weight (HSW) were recorded.

Furthermore, 22 qualitative parameters on cotyledon, plant, leaf, stem, flower, seed, fruit, were descriptively assessed for three and five replicates from Bandarawela and Welimada sites respectively. The color of the cotyledon and the plant growth habit were recorded to distinguish among the species/varieties according to the RHS Color Chart (Royal Horticultural Society, 2001). The parameters recorded to assess the leaf variability were leaf blade color, blade lobbing and the leaf blade tip angle. The stem characteristics recorded in this study were the color of the stem, and presence of hairs and prickles on the stem. The floral parameters included the type of the inflorescence, the color of corolla, position of the stigma and the presence of prickles in the pedicel and color of the seeds. The shape of the fruit apex, fruit flesh density, relative fruit calyx length, color of the petiole, the position of the fruit, the color of fruits, the nature of fruit curvature, cross section and locules, and the number of prickles in calyx were recorded as fruit characteristics. These parameters were used to assess the variability among the species/varieties. 


\section{DNA extraction and PCR}

Immature, fresh leaf samples were used in the DNA extraction process. DNA was extracted using modified CTAB (hexadecyl trimethyl ammonium bromide) protocol (Porebski et al., 1997). PCR amplification was performed in TP600: Takara (Otsu Shiga, Japan) thermal cycler using eight DNA barcoding primer pairs (Table 1) in a $15 \mu$ l the PCR reaction mixture with Go Taq Green Master Mix $(7.5 \mu \mathrm{l}), 10 \mu \mathrm{M}$ forward and reverse primers $(0.5 \mu \mathrm{l}$ each) and 10 $\mu \mathrm{M}$ Spermidine $(3.5 \mu \mathrm{l})$. The PCR profiles used were as given in Table 1 (Levin et al., 2003; Shaw et al., 2005). The volume of template DNA for each marker was optimized considering each marker profile. The standard PCR protocol was modified for certain markers for an optimal amplification (Table 1).

\section{DNA sequencing}

The viable PCR products of two selected DNA markers, which are commonly used for more profound phylogenetic relationship analysis in plants were purified using Qiagen Qiaquick PCR purification kit (Catalog number: 28104, Qiagen, Hilden, Germany) and sequenced using ABI 3500 automated sequencer (Catalog number 622-0010).

\section{Data analysis}

All the quantitative morphometric data were subjected to normality testing in Minitab 17 (Minitab Inc. USA), and General Linear Model (GLM) and LS means/pdiff mean separation procedures using statistical package SAS 9.4 (SAS Institute, NC, Cary, USA). Following the data analysis, a dendrogram was constructed for the vegetative and reproductive data using the algorithms of Complete Linkage and Pearson Distance method in Minitab 17 (Minitab Inc. USA). Principal component analysis (PCA) was conducted using reproductive, vegetative and combined data in Minitab 17 (Minitab Inc. USA). The principal component 1 (PC 1) and principal component 2 (PC 2) were employed in drawing scatter plots. All the PCs were used to draw dendrogram using Euclidean distances.

\section{Phylogenetic analysis}

The raw sequencing data generated for two markers $r b c L$ and $\operatorname{trn} L$-trnF were first visualized in MEGA 7 (Kumar et al., 2016) in order to define the initial and end noise. Then, the trimmed datasets were subjected separately to a BLAST search and homology sequences with high E values (threshold $\mathrm{E}$ value $=10^{-5}$ ) were retrieved (Table 2$)$. The selected reference sequences were then aligned with the sequences by ClustalW algorithm (Thompson et al., 1994) in MEGA 7 (Kumar et al., 2016) with manual editing. The evolutionary relationship of S. torvum, S. pubescens and S. hispidum was inferred based on the phylogenetic tree reconstructed based on $r b c L$ and $t r n L-t r n F$. A tree search was conducted in Maximum Likelihood (ML) framework in RAxML (Stamatakis, 2006) through a rapid bootstrap algorithm (Stamatakis, 2008) for 1000 iterations and GTRGAMMA (Rodriguez et al., 1990) as the evolutionary model to compensate the dataset. All the bootstrap bipartitions were used to get a single tree topology by constraining the bootstrap values to ML consensus tree. Further modification of the final majority rule consensus tree was carried out using Figtree 1.4.3 (Rambaut, 2014). Furthermore, to support the analysis, a tree was built in the Bayesian framework and interpretations on the best nucleotide substitutions were made by carrying out a model selection in Akaike Information Criteria (AIC) (Akaike, 1974) and corrected Akaike Information Criteria (AICc) (Cavanaugh, 1997) in J model test (Posada, 2008). 
Table 1. DNA Barcoding markers and PCR conditions.

\begin{tabular}{|c|c|c|c|c|c|c|c|c|c|c|c|c|}
\hline \multirow[b]{2}{*}{ A marker } & \multirow[b]{2}{*}{ Sequence $\left(5^{\prime}-3^{\prime}\right)$} & \multicolumn{2}{|c|}{ Initial denaturation } & \multicolumn{2}{|c|}{ Denaturation } & \multicolumn{2}{|c|}{ Annealing } & \multicolumn{2}{|c|}{ Extension } & \multicolumn{2}{|c|}{ Final extension } & \multirow[t]{2}{*}{ Reference } \\
\hline & & $\mathrm{T}\left({ }^{\circ} \mathrm{C}\right)$ & Time & $\begin{array}{l}\mathbf{T} \\
\left({ }^{\circ} \mathrm{C}\right)\end{array}$ & Time & $\begin{array}{l}\mathrm{T} \\
\left({ }^{\circ} \mathrm{C}\right) \\
\end{array}$ & Time & $\begin{array}{l}\mathrm{T} \\
\left({ }^{\circ} \mathrm{C}\right)\end{array}$ & Time & $\begin{array}{l}\mathrm{T} \\
\left({ }^{\circ} \mathrm{C}\right)\end{array}$ & Time & \\
\hline trnH-psbA & $\begin{array}{l}\text { F- CGCGCATGGTGGATTCACAATCC } \\
\text { R- GTTATGCATGAACGTAATGCTC }\end{array}$ & 98 & $45 \mathrm{sec}$ & 98 & $10 \mathrm{sec}$ & 64 & $30 \mathrm{sec}$ & 72 & $40 \mathrm{sec}$ & 72 & 10 mins & $\begin{array}{l}\text { Tate and Simpson (2003) } \\
\text { Sang } \text { et al. (1997) }\end{array}$ \\
\hline rbcL & $\begin{array}{l}\text { F-ATGTCACCACAAACAGAGACTAAAGC } \\
\text { R- GTAAAATCAAGTCCACCRCG }\end{array}$ & 98 & $45 \mathrm{sec}$ & 98 & $10 \mathrm{sec}$ & 55 & $30 \mathrm{sec}$ & 72 & $40 \mathrm{sec}$ & 72 & 10 mins & $\begin{array}{l}\text { Levin et al. }(2003) \\
\text { Kress et al. }(2009)\end{array}$ \\
\hline trnL-trnF spacer & $\begin{array}{l}\text { F- CGA AAT CGG TAG ACG CTA CG } \\
\text { R- ATT TGA ACT GGT GAC ACG AG }\end{array}$ & 80 & 5 mins & 94 & $1 \mathrm{~min}$ & 50 & $1 \mathrm{~min}$ & 72 & 2 mins & 94 & 4 mins & Taberlet et al. (1991) \\
\hline $\operatorname{trn} S^{G C U}-\operatorname{trn} G^{U U C}$ & $\begin{array}{l}\text { F- AGA TAG GGA TTC GAA CCC TCG GT } \\
\text { R- GTA GCG GGA ATC GAA CCC GCA TC }\end{array}$ & 80 & 5 mins & 95 & $1 \mathrm{~min}$ & 66 & $4 \mathrm{~min}$ & 66 & 4 mins & 66 & 10 mins & Shaw et al. (2005) \\
\hline atpB-rbcL spacer & $\begin{array}{l}\text { F-GAAGTAGTAGGATTGATTCTC } \\
\text { R-TACAGTTGTCCATGTACCAG }\end{array}$ & 94 & 4 mins & 94 & $30 \mathrm{sec}$ & 45 & $30 \mathrm{sec}$ & 72 & 2 mins & 72 & 5 mins & Hoot and Taylor (2001) \\
\hline atpB gene & $\begin{array}{l}\text { F-TATGAGAATCAATCCTACTACTTCT } \\
\text { R-TCAGTACACAAAGATTTAAGGTCAT }\end{array}$ & 92 & 3 mins & 92 & $1 \mathrm{~min}$ & 55 & $1 \mathrm{~min}$ & 72 & 3 mins & 72 & 7 mins & Hoot et al. (1995) \\
\hline matK-trnT spacer & $\begin{array}{l}\text { F-GCATAAATATAYTCCYGAAARATAAGTGG } \\
\text { R-TGGGTTGCTAACTCAATGG }\end{array}$ & 95 & $90 \mathrm{sec}$ & 95 & $30 \mathrm{sec}$ & 48 & $1 \mathrm{~min}$ & 68 & 2 mins & 68 & 20 mins & $\begin{array}{l}\text { Wicke and Quandt } \\
\text { (2009) }\end{array}$ \\
\hline $\begin{array}{l}\operatorname{trnL} L(t R N A-l e u \\
\text { gene) }\end{array}$ & $\begin{array}{l}\text { F-CGAAATCGGTAGACGCTACG } \\
\text { R-GGGGATAGAGGGACTTGAAC }\end{array}$ & 95 & $\begin{array}{l}10 \\
\text { mins }\end{array}$ & 95 & $30 \mathrm{sec}$ & 50 & $30 \mathrm{sec}$ & 72 & 2 mins & 94 & 4 mins & Taberlet et al. (2007) \\
\hline
\end{tabular}


Then, the criteria for the best model were used to construct the tree in the Bayesian framework using MrBays (Huelsenbeck and Ronquist, 2001). Four Markov Chain Monte Carlo (MCMC) were implemented for 50 million cycles to generate precise posterior probability distributions. Burn-in point of the analysis was set to 5000 generations and $10 \%$ of the trees generated initially were omitted as burn-in. The 50\% majority rule consensus tree out of the remaining trees was drawn. The posterior probability values from each branch were subsequently inferred. The model selection and all the tree constructions were carried out in CIPRES super computer (Miller et al., 2010). Finally, the resemblance of Bayesian and ML trees was modelled, and the posterior probability values were incoporated to the nodes of the Bayesian tree.

Table 2. The GenBank sequences used in the present study.

\begin{tabular}{|c|c|c|}
\hline Accession No. & Species name & Reference \\
\hline AY266235 & Solanum sisymbriifolium & Bohs 2004 \\
\hline AY266246 & S. torvum & Bohs 2004 \\
\hline DQ180394 & S. aethiopicum & Weese and Bohs 2007 \\
\hline DQ392958 & S. capense & NCBI \\
\hline DQ392959 & S. cyaneo-purpureum & NCBI \\
\hline DQ392961 & S. tomentosum & NCBI \\
\hline DQ812103 & S. anguivi & Bohs et al., 2007 \\
\hline EU176156 & S. richardii & NCBI \\
\hline EU176158 & S. supinum & NCBI \\
\hline GQ163556 & S. rigescentoides & NCBI \\
\hline GU590997 & S. albidum & Stern et al., 2011 \\
\hline GU590999 & S. asperolanatum & Stern et al., 2011 \\
\hline GU591003 & S. bolivianum & Stern et al., 2011 \\
\hline GU591007 & S. chrysotrichum & Stern et al., 2011 \\
\hline GU591013 & S. donianum & Stern et al., 2011 \\
\hline GU591016 & S. glutinosum & Stern et al., 2011 \\
\hline GU591023 & S. lanceolatum & Stern et al., 2011 \\
\hline GU591035 & S. pluviale & Stern et al., 2011 \\
\hline GU591044 & S. stellativelutinum & Stern et al., 2011 \\
\hline HQ457406 & S. metrobotryon & Stern et al., 2011 \\
\hline HQ721897 & S. aethiopicum & NCBI \\
\hline HQ721899 & S. anguivi & NCBI \\
\hline HQ721909 & S. catombelense & NCBI \\
\hline HQ721927 & S. mauense & NCBI \\
\hline HQ721941 & S. ruvu & NCBI \\
\hline HQ721958 & S. zanzibarense & NCBI \\
\hline KC539171 & S. euacanthum & Wahlert et al., 2014 \\
\hline KC539172 & S. hasslerianum & Wahlert et al., 2014 \\
\hline
\end{tabular}




\begin{tabular}{|c|c|c|}
\hline Accession No. & Species name & Reference \\
\hline KC539180 & S. sisymbriifolium & Wahlert et al., 2014 \\
\hline KU719749 & S. trilobatum & Aubriot et al., 2016 \\
\hline KU719755 & S. dammerianum & Aubriot et al., 2016 \\
\hline KU719760 & S. poka & Aubriot et al., 2016 \\
\hline KU719781 & S. pseudosaponaceum & Aubriot et al., 2016 \\
\hline KU719784 & S. torvum & Aubriot et al., 2016 \\
\hline KU719786 & S. trilobatum & Aubriot et al., 2016 \\
\hline KU719790 & S. torvum & Aubriot et al., 2016 \\
\hline AB586589 & Solanum sp. & Tobe et al., 2010 \\
\hline JN407385 & S. torvum & NCBI \\
\hline JN407386 & S. torvum & NCBI \\
\hline KF270202 & S. environmental & NCBI \\
\hline KT178124 & S. triflorum & Aust et al., 2015 \\
\hline KY293568 & S. nigrum & $\mathrm{NCBI}$ \\
\hline MH283707 & S. trilobatum & Aubriot et al., 2018 \\
\hline MH283708 & S. melongena & Aubriot et al., 2018 \\
\hline MH283709 & S. glabratum & Aubriot et al., 2018 \\
\hline MH283710 & S. umtuma & Aubriot et al., 2018 \\
\hline MH283711 & S. melongena & Aubriot et al., 2018 \\
\hline MH283712 & S. violaceum & Aubriot et al., 2018 \\
\hline MH283713 & S. incanum & Aubriot et al., 2018 \\
\hline MH283715 & S. polhillii & Aubriot et al., 2018 \\
\hline MH283717 & S. aethiopicum & Aubriot et al., 2018 \\
\hline MH283718 & S. campylacanthum & Aubriot et al., 2018 \\
\hline MH283719 & S. usambarense & Aubriot et al., 2018 \\
\hline MH283720 & S. agnewiorum & Aubriot et al., 2018 \\
\hline MH283721 & S. incanum & Aubriot et al., 2018 \\
\hline MH283722 & S. richardii & Aubriot et al., 2018 \\
\hline MH283724 & S. anguivi & Aubriot et al., 2018 \\
\hline MH360739 & S. nigrum & NCBI \\
\hline
\end{tabular}

\section{RESULTS AND DISCUSSION}

\section{Variation of the quantitative morphological parameters}

Mean separation of a total of 29 quantitative parameters including 11 vegetative and 18 reproductive parameters for three Solanum species are given in the Table 3. The individual effects of site (Bandarawela and Welimada), species/variety (S. torvum 1, S. torvum 2, S. 
pubescens and S. hispidum) and the integration effect of site $\times$ species/variety interaction were assessed on all the parameters.

The mean values of CL, CW, LBL, LBW, NLP, PlH, MCW, and NB were found to be significantly variable among the species/varieties, and so as the site species/variety interaction. A significantly highest mean CL was recorded for $S$. hispidum $(2.7 \mathrm{~cm})$, while it was the lowest in $S$. pubescens $(1.46 \mathrm{~cm})$ (Table $3, P<0.05)$. When considering the site $\times$ species/variety interaction, the highest CL was recorded for $S$. hispidum in both the sites $(2.7 \mathrm{~cm})$. Similarly, $\mathrm{CW}$ was found to be the highest for $S$. hispidum $(8.58 \mathrm{~cm})$ whereas $S$. pubescens was the lowest $(4.93 \mathrm{~cm})$. However, no significant difference of CL/CW ratio could be recorded among the three species in two sites (Table $3, P<0.05$ ), thus suggesting that $\mathrm{CL} / \mathrm{CW}$ could not be employed in the delimitation of studied Solanum species.

The morphological variation of leaf parameters also could be employed to differentiate species. The mean values of LBL, LBW, and LPL were the highest for $S$. hispidum $(37.19 \mathrm{~cm}, 34.83$ $\mathrm{cm}$ and $12.59 \mathrm{~cm}$ respectively). On the contrary, $S$. pubescens were found to be the lowest for each of the three parameters mentioned above $(6.15 \mathrm{~cm}, 6.20 \mathrm{~cm}$, and $2.69 \mathrm{~cm}$, respectively) (Table 3, $P<0.05$ ). Moreover, the highest mean values of LBL, LBW, and LPL were recorded by $S$. pubescens in Bandarawela site than Welimada site. The mean values of LBTA were significantly variable depending on site, species/variety and site $\times$ species/variety interaction. Accordingly, LBTA was found to be very high in Welimada area. Regarding the effect of the species/variety, S. torvum 2 and $S$. pubescens varieties were shown to have the highest LBTA values (67.25 and $69.17 \mathrm{~cm}$, respectively). The variation of both the micro-climatic conditions and the genetic components may result in the observed differences in leaf morphology.

Furthermore, NLP was significantly high in S. hispidum $(21.42 \mathrm{~cm}$ ) and was highly variable concerning the site $\times$ species/variety interaction. It was also noticed that the mean values of $\mathrm{PlH}$ for S. pubescens in both Bandarawela and Welimada areas were markedly low $(98.18 \mathrm{~cm}$ and $160.84 \mathrm{~cm}$, respectively) compared to other site $\times$ species/variety interactions (Table 3 , $P<0.05)$. The significant highest MCW was recorded for $S$. torvum $2(322.72 \mathrm{~cm})$. The species $S$. pubescens, in contrast, recorded the lowest MCW $(79.46 \mathrm{~cm})$. NB was markedly high in $S$. torvum species (S. torvum 1-20, S. torvum 2-19) while it was the lowest in S. pubescens (5.77). However, all the mean values of MCW and NB recorded were highly variable depending on site $\times$ species/variety interaction (Table 3,P<0.05). Therefore, the variation in all the vegetative characters evaluated in this study except $\mathrm{CL} / \mathrm{CW}$, indicate their potential applicability in delimiting of the species. Similar levels of variations in plant, canopy and leaf characters of Solanum spp. have been reported in Jeyakumar et al. (2016) and Bello et al. (2013) showing higher genetic determination in the considered traits.

\section{Variation of the reproductive traits}

Out of the 18 reproductive parameters, NFPI, FD, PL, PW, AW, FB, LS, TS, yield, SD, and HSW were not significantly different between two sites. However, NFPI was the highest in $S$. torvum 1 and $S$. torvum 2 varieties (41.31 and 41.00, respectively) and the lowest in $S$. pubescens (12). In contrast, NFPI was highly variable regarding the site $\times$ species/variety interaction (Table 4, P<0.05). However, other floral traits; FD, PL, PW, LSE, AL, AW, LS are the highest in $S$. pubescens $(5.06 \mathrm{~cm}, 1.66 \mathrm{~cm}, 0.91 \mathrm{~cm}, 13.80 \mathrm{~cm}, 12.02 \mathrm{~cm}, 3.01 \mathrm{~cm}, 2.06$ $\mathrm{cm}$ respectively) and some of the seed traits; SD, and HSW were the highest in S. hispidum $(0.31 \mathrm{~cm}$, and $0.29 \mathrm{~g}$ respectively). Moreover, in both the sites, $S$. pubescens recorded high mean values for FD (Banadarawela-4.98 cm, Welimada-5.14 cm), PL (Banadarawela-1.65 $\mathrm{cm}$, Welimada-1.68 cm), PW (Banadarawela-0.9 cm, Welimada-0.91 cm), AL 
(Banadarawela-12.62 cm, Welimada-11.45 cm), LS (Banadarawela-2.07 cm, Welimada-2.10 $\mathrm{cm}$ ), SD (Banadarawela-0.31 cm, Welimada-0.30 cm), and HSW (Banadarawela- $0.27 \mathrm{~g}$, Welimada-0.30 g) (Table 4, $P<0.05)$.

Floral characters, in contrast were not significantly different with respect to the site $x$ species/variety interaction. Moreover, the mean values of LSE, AL and DF were significantly high in trees grown in Bandarawela site than those in Welimada site $(9.83 \mathrm{~cm}, 8.29 \mathrm{~cm}$ and 124.74 respectively). S. torvum 1 recorded the highest DF (133.09) while S. pubescens recorded the lowest (122.78) (Table 4, $P<0.05$ ). Also, the mean values of FL and FL/FB ratio were significantly high in Welimada site $(1.38 \mathrm{~cm}, 1.5$ respectively). However, S. pubescens recorded comparatively a less mean FL $(1.06 \mathrm{~cm})$ and less mean FB value $(1.04 \mathrm{~cm})$ whereas, other species were found to have fruits with similar length and breadth measurements (Table 4, $P<0.05)$. The lowest TS, HFW, and yield were recorded by $S$. pubescens $(0.34 \mathrm{~cm}, 68.81 \mathrm{~g}$, and $14.01 \mathrm{~g})$ and the yield was significantly high in $S$. torvum $2(242.23 \mathrm{~g})$. Despite the differences in overall yield, IFW was significantly different among the species/varieties, thus suggesting the fact that, there was a correlation between IFW and yield traits. However, all the reproductive traits except FL/FB were useful to distinguish among the species quantitatively (Table $4, P<0.05)$. Similar levels of variability in floral, seed and fruit morphology have been reported in Jeyakumar et al., (2016).

\section{Analysis of qualitative parameters}

Qualitative characters provided an indispensable source for the differentiation of species. The variability of the qualitative morphometric parameters was descriptively assessed and reported in Table 5 and Table 6. Morphological variability of cotyledon, plant, leaf, stem, flower, seed and fruit of Solanum species/varieties were descriptively evaluated at vegetative, flowering and harvesting stages.

The cotyledon color at the seedling stage was variable among the species. S. torvum were found to have green cotyledons, while those of the $S$. pubescens and S. hispidum were light violet. The growth habits of Solanum spp. were different, as the plants of $S$. torvum and $S$. pubescens species developed an upright growth habit and the stems of $S$. hispidum plants showed an intermediate growth pattern (Table 5). Three parameters of leaf were assessed to detect the variability among the species. Accordingly, the color of the leaf blade of $S$. torvum sp. was moderately olive green, whereas $S$. pubescens and $S$. hispidum possessed leaves with greyish green. Leaf blade lobbing was slightly variable among the species. The blade lobbing of $S$. torvum and S. hispidum were strong, while that of the $S$. pubescens was intermediate. However, it was noticed that there was no any difference in the leaf blade tip among the species, such that all the leaves had an acute tip (Table 5) (Plate $1 \mathrm{~A}$ and B). 
Table 3. The means of the parameters explaining vegetative morphology.

\begin{tabular}{|c|c|c|c|c|c|c|c|c|c|c|c|c|}
\hline & Variable & 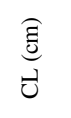 & $\begin{array}{l}\text { 运 } \\
\text { z }\end{array}$ & $\frac{z}{3}$ & $\begin{array}{l}\text { 跑 } \\
\text { 品 }\end{array}$ & 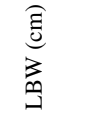 & 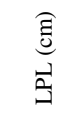 & 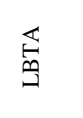 & 岁 & 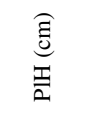 & है है & 乙 \\
\hline \multirow[t]{2}{*}{ Site } & Bandarawela & $2.04^{\mathrm{a}}$ & $6.40^{\mathrm{a}}$ & $3.17^{\mathrm{a}}$ & $22.81^{\mathrm{a}}$ & $21.08^{\mathrm{a}}$ & $5.60^{b}$ & $60.29^{b}$ & $6.48^{\mathrm{a}}$ & $215.81^{\mathrm{a}}$ & $267.31^{\mathrm{a}}$ & $15.35^{\mathrm{a}}$ \\
\hline & Welimada & $2.03^{\mathrm{a}}$ & $6.09^{\mathrm{a}}$ & $3.32^{\mathrm{a}}$ & $21.79^{\mathrm{a}}$ & $20.59^{\mathrm{a}}$ & $6.26^{\mathrm{a}}$ & $64.81^{\mathrm{a}}$ & $5.89^{\mathrm{a}}$ & $226.78^{\mathrm{a}}$ & $269.06^{\mathrm{a}}$ & $16.25^{\mathrm{a}}$ \\
\hline Species & S.torvum 1 & $1.97^{\mathrm{b}}$ & $5.96^{b}$ & $3.32^{\mathrm{a}}$ & $23.80^{\mathrm{b}}$ & $21.67^{\mathrm{b}}$ & $6.24^{b}$ & $63.86^{b}$ & $4.95^{b}$ & $236.96^{\mathrm{a}}$ & $311.49^{b}$ & $19.55^{\mathrm{a}}$ \\
\hline \multirow{3}{*}{ / Variety } & S.torvum 2 & $2.01^{b}$ & $6.03^{b}$ & $3.36^{\mathrm{a}}$ & $23.83^{b}$ & $21.97^{\mathrm{b}}$ & $5.72^{\mathrm{b}}$ & $67.25^{\mathrm{a}}$ & $3.10^{\mathrm{c}}$ & $239.03^{\mathrm{a}}$ & $322.72^{\mathrm{a}}$ & $18.72^{\mathrm{a}}$ \\
\hline & S. hispidum & $2.70^{\mathrm{a}}$ & $8.58^{\mathrm{a}}$ & $3.17^{\mathrm{a}}$ & $37.10^{\mathrm{a}}$ & $34.83^{\mathrm{a}}$ & $12.59^{\mathrm{a}}$ & $44.32^{\mathrm{c}}$ & $21.42^{\mathrm{a}}$ & $254.87^{\mathrm{a}}$ & $283.21^{\text {b }}$ & $15.27^{\mathrm{b}}$ \\
\hline & S. pubescens & $1.46^{\mathrm{c}}$ & $4.93^{\mathrm{c}}$ & $3.12^{\mathrm{a}}$ & $6.15^{\mathrm{c}}$ & $6.20^{\mathrm{c}}$ & $2.69^{\mathrm{c}}$ & $69.17^{\mathrm{a}}$ & $4.44^{b}$ & $133.25^{\mathrm{a}}$ & $79.46^{c}$ & $5.77^{\mathrm{c}}$ \\
\hline Site $\times$ & S.torvum $1^{*}$ & $1.99^{\mathrm{b}}$ & $5.69^{\mathrm{c}}$ & $3.55^{\mathrm{a}}$ & $24.67^{c}$ & $22.33^{\mathrm{c}}$ & $5.57^{\mathrm{b}}$ & $59.19^{\mathrm{b}}$ & $4.92^{b}$ & $236.41^{\mathrm{a}}$ & $317.80^{a}$ & $18.78^{\mathrm{a}}$ \\
\hline Species/ & S.torvum $2^{*}$ & $2.00^{\mathrm{b}}$ & $6.10^{\mathrm{c}}$ & $3.25^{\mathrm{a}}$ & $22.91^{\mathrm{c}}$ & $20.32^{\mathrm{c}}$ & $5.26^{b}$ & $66.44^{\mathrm{a}}$ & $4.05^{b}$ & $234.78^{\mathrm{a}}$ & $334.59^{\mathrm{a}}$ & $18.04^{\mathrm{a}}$ \\
\hline \multirow[t]{6}{*}{ Variety } & S. hispidum ${ }^{*}$ & $2.70^{\mathrm{a}}$ & $9.44^{\mathrm{a}}$ & $2.87^{\mathrm{a}}$ & $40.69^{\mathrm{a}}$ & $37.54^{\mathrm{a}}$ & $12.65^{\mathrm{a}}$ & $42.18^{\mathrm{c}}$ & $21.64^{\mathrm{a}}$ & $256.20^{\mathrm{a}}$ & $262.03^{\mathrm{a}}$ & $15.19^{\mathrm{b}}$ \\
\hline & S. pubescens" & $1.47^{\mathrm{c}}$ & $5.13^{\mathrm{d}}$ & $3.02^{\mathrm{a}}$ & $5.28^{\mathrm{d}}$ & $5.85^{\mathrm{d}}$ & $2.65^{\mathrm{c}}$ & $66.99^{\mathrm{a}}$ & $4.08^{b}$ & $98.18^{b}$ & $64.95^{\mathrm{b}}$ & $5.82^{\mathrm{c}}$ \\
\hline & S.torvum $\mathbf{1}^{\#}$ & $1.95^{\mathrm{b}}$ & $6.25^{\mathrm{c}}$ & $3.09^{\mathrm{a}}$ & $22.95^{\mathrm{c}}$ & $21.01^{c}$ & $7.00^{\mathrm{b}}$ & $67.93^{\mathrm{a}}$ & $4.97^{\mathrm{b}}$ & $237.52^{\mathrm{a}}$ & $305.06^{\mathrm{a}}$ & $20.29^{\mathrm{a}}$ \\
\hline & S.torvum $2^{\#}$ & $2.02^{\mathrm{b}}$ & $5.96^{c}$ & $3.47^{\mathrm{a}}$ & $24.76^{\mathrm{c}}$ & $23.63^{\mathrm{c}}$ & $6.22^{\mathrm{b}}$ & $68.04^{\mathrm{a}}$ & $2.37^{\mathrm{c}}$ & $243.21^{\mathrm{a}}$ & $310.39^{\mathrm{a}}$ & $19.38^{\mathrm{a}}$ \\
\hline & S. hispidum ${ }^{\#}$ & $2.70^{\mathrm{a}}$ & $7.80^{b}$ & $3.47^{\mathrm{a}}$ & $33.66^{b}$ & $32.21^{\mathrm{b}}$ & $12.89^{\mathrm{a}}$ & $46.26^{\mathrm{a}}$ & $21.20^{\mathrm{a}}$ & $253.53^{\mathrm{a}}$ & $302.90^{\mathrm{a}}$ & $15.36^{b}$ \\
\hline & S. pubescens" & $1.45^{\mathrm{c}}$ & $4.73^{\mathrm{d}}$ & $3.22^{\mathrm{a}}$ & $7.01^{\mathrm{d}}$ & $6.55^{\mathrm{d}}$ & $2.74^{\mathrm{c}}$ & $71.21^{\mathrm{a}}$ & $4.82^{b}$ & $160.84^{b}$ & $97.71^{\mathrm{b}}$ & $5.73^{\mathrm{c}}$ \\
\hline
\end{tabular}

Means denoted by the same letters within the column are not significantly different at $P<0.05 . \mathrm{CL}=\mathrm{Cotyledon}$ length, $\mathrm{CW}=\mathrm{Cotyledon}$ width, $\mathrm{CL} / \mathrm{CW}=\mathrm{Cotyledon}$ length $/$ cotyledon width ratio, $\mathrm{LBL}=$ Leaf blade length, $\mathrm{LBW}=$ Leaf blade width, $\mathrm{LPL}=$ Leaf petiole length, LBTA= Leaf blade tip angle, NLP= Number of leaf prickles, $\mathrm{PIH}=\mathrm{Plant}$ height, $\mathrm{MCW}=\mathrm{Mean}$ canopy width, NB= Number of

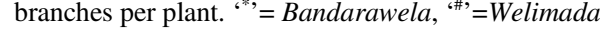

Table 4. The variation of the reproductive morphology.

\begin{tabular}{|c|c|c|c|c|c|c|c|c|c|c|c|c|c|c|c|c|c|c|c|}
\hline \multicolumn{2}{|c|}{ Variable } & NFPI & $\begin{array}{l}\text { FD } \\
(\mathbf{c m})\end{array}$ & $\begin{array}{l}\text { PL } \\
(\mathbf{c m})\end{array}$ & $\begin{array}{l}\mathbf{P W} \\
(\mathbf{c m})\end{array}$ & $\begin{array}{l}\text { LSE } \\
(\mathbf{c m})\end{array}$ & $\begin{array}{l}\mathbf{A L} \\
(\mathbf{c m})\end{array}$ & $\begin{array}{l}\text { AW } \\
(\mathbf{c m})\end{array}$ & DF & $\begin{array}{l}\text { FL } \\
(\mathbf{c m})\end{array}$ & $\begin{array}{l}\mathbf{F B} \\
(\mathbf{c m})\end{array}$ & FL/FB & $\begin{array}{c}\mathbf{L S} \\
(\mathbf{c m})\end{array}$ & $\begin{array}{c}\text { TS } \\
(\mathbf{c m})\end{array}$ & $\begin{array}{c}\text { IFW } \\
(\mathrm{g})\end{array}$ & $\begin{array}{c}\text { HFW } \\
(\mathrm{g})\end{array}$ & $\begin{array}{c}\text { Yield } \\
\text { (g) }\end{array}$ & $\begin{array}{c}\text { SD } \\
(\mathbf{c m})\end{array}$ & $\begin{array}{c}\text { HSW } \\
(\mathrm{g})\end{array}$ \\
\hline \multirow{3}{*}{ Site } & Bandarawela & $28.14^{\mathrm{a}}$ & $3.54^{\mathrm{a}}$ & $1.27^{\mathrm{a}}$ & $0.77^{\mathrm{a}}$ & $9.83^{\mathrm{a}}$ & $8.29^{\mathrm{a}}$ & $2.44^{\mathrm{a}}$ & $124.74^{\mathrm{a}}$ & $0.93^{b}$ & $1.22^{\mathrm{a}}$ & $0.45^{\mathrm{b}}$ & $1.61^{\mathrm{a}}$ & $0.42^{\mathrm{a}}$ & $1.32^{\mathrm{a}}$ & $107.85^{\mathrm{a}}$ & $60.35^{\mathrm{c}}$ & $0.23^{\mathrm{a}}$ & $0.16^{\mathrm{a}}$ \\
\hline & Welimada & $25.97^{\mathrm{a}}$ & $3.52^{\mathrm{a}}$ & $1.29^{\mathrm{a}}$ & $0.73^{\mathrm{a}}$ & $8.50^{\mathrm{b}}$ & $7.63^{b}$ & $2.49^{\mathrm{a}}$ & $119.70^{\mathrm{b}}$ & $1.38^{\mathrm{a}}$ & $1.22^{\mathrm{a}}$ & $1.50^{\mathrm{a}}$ & $1.60^{\mathrm{a}}$ & $0.43^{\mathrm{a}}$ & $1.21^{\mathrm{a}}$ & $110.15^{\mathrm{a}}$ & $74.73^{\mathrm{c}}$ & $0.23^{\mathrm{a}}$ & $0.16^{\mathrm{a}}$ \\
\hline & S. torvum 1 & $41.31^{\mathrm{a}}$ & $2.71^{\mathrm{c}}$ & $1.12^{\mathrm{c}}$ & $0.71^{\mathrm{b}}$ & $6.65^{\mathrm{c}}$ & $5.85^{\mathrm{c}}$ & $2.18^{\mathrm{b}}$ & $133.09^{\mathrm{a}}$ & $1.22^{\mathrm{a}}$ & $1.29^{\mathrm{a}}$ & $0.85^{\mathrm{a}}$ & $1.43^{\mathrm{b}}$ & $0.44^{\mathrm{a}}$ & $1.24^{\mathrm{a}}$ & $115.16^{\mathrm{a}}$ & $119.75^{\mathrm{b}}$ & $0.19^{\mathrm{c}}$ & $0.11^{\mathrm{c}}$ \\
\hline \multirow{4}{*}{ Species/Variety } & S. torvum 2 & $41.00^{\mathrm{a}}$ & $2.68^{\mathrm{c}}$ & $1.10^{\mathrm{c}}$ & $0.69^{\mathrm{b}}$ & $6.70^{\mathrm{c}}$ & $5.79^{\mathrm{c}}$ & $2.33^{\mathrm{b}}$ & $125.10^{\mathrm{b}}$ & $1.20^{\mathrm{a}}$ & $1.27^{\mathrm{a}}$ & $0.82^{\mathrm{a}}$ & $1.46^{\mathrm{b}}$ & $0.47^{\mathrm{a}}$ & $1.22^{\mathrm{a}}$ & $120.34^{\mathrm{a}}$ & $242.23^{\mathrm{a}}$ & $0.19^{c}$ & $0.11^{\mathrm{c}}$ \\
\hline & S. hispidum & $25.50^{\mathrm{b}}$ & $4.24^{\mathrm{b}}$ & $1.31^{\mathrm{b}}$ & $0.72^{\mathrm{b}}$ & $11.36^{\mathrm{b}}$ & $9.83^{\mathrm{b}}$ & $2.43^{b}$ & $108.51^{\mathrm{d}}$ & $1.28^{\mathrm{a}}$ & $1.25^{\mathrm{a}}$ & $0.96^{\mathrm{a}}$ & $1.54^{\mathrm{b}}$ & $0.46^{\mathrm{a}}$ & $1.36^{\mathrm{a}}$ & $122.69^{\mathrm{a}}$ & $50.05^{\mathrm{c}}$ & $0.31^{\mathrm{a}}$ & $0.29^{\mathrm{a}}$ \\
\hline & S. pubescens & $12.37^{\mathrm{c}}$ & $5.06^{\mathrm{a}}$ & $1.66^{\mathrm{a}}$ & $0.91^{\mathrm{a}}$ & $13.80^{\mathrm{a}}$ & $12.02^{\mathrm{a}}$ & $3.01^{\mathrm{a}}$ & $122.78^{\mathrm{c}}$ & $1.06^{\mathrm{b}}$ & $1.04^{\mathrm{b}}$ & $0.97^{\mathrm{a}}$ & $2.06^{\mathrm{a}}$ & $0.34^{\mathrm{b}}$ & $0.69^{b}$ & $68.81^{\mathrm{b}}$ & $14.01^{\mathrm{d}}$ & $0.22^{\mathrm{b}}$ & $0.17^{\mathrm{b}}$ \\
\hline & S. torvum $1^{*}$ & $39.37^{\mathrm{a}}$ & $2.75^{\mathrm{c}}$ & $1.13^{\mathrm{c}}$ & $0.75^{\mathrm{b}}$ & $7.13^{\mathrm{c}}$ & $6.11^{\mathrm{c}}$ & $2.17^{\mathrm{a}}$ & $141.53^{\mathrm{a}}$ & $0.90^{\mathrm{d}}$ & $1.27^{\mathrm{a}}$ & $0.40^{\mathrm{b}}$ & $1.43^{\mathrm{b}}$ & $0.42^{\mathrm{a}}$ & $1.18^{\mathrm{a}}$ & $112.91^{\mathrm{a}}$ & $82.63^{\mathrm{c}}$ & $0.19^{c}$ & $0.11^{\mathrm{c}}$ \\
\hline \multirow{7}{*}{$\begin{array}{l}\text { Site } \times \\
\text { species/variety }\end{array}$} & S. torvum $2^{*}$ & $36.18^{\mathrm{a}}$ & $2.73^{\mathrm{c}}$ & $1.10^{\mathrm{c}}$ & $0.75^{\mathrm{b}}$ & $7.35^{\mathrm{c}}$ & $6.08^{\mathrm{c}}$ & $2.17^{\mathrm{a}}$ & $126.51^{\mathrm{b}}$ & $0.84^{\mathrm{d}}$ & $1.27^{\mathrm{a}}$ & $0.35^{\mathrm{b}}$ & $1.44^{\mathrm{b}}$ & $0.48^{\mathrm{a}}$ & $1.21^{\mathrm{a}}$ & $117.65^{\mathrm{a}}$ & $223.86^{\mathrm{a}}$ & $0.19^{\mathrm{c}}$ & $0.12^{\mathrm{c}}$ \\
\hline & S. hispidum ${ }^{*}$ & $27.38^{\mathrm{b}}$ & $4.23^{\mathrm{b}}$ & $1.29^{\mathrm{b}}$ & $0.71^{\mathrm{b}}$ & $12.35^{\mathrm{a}}$ & $10.10^{\mathrm{b}}$ & $2.41^{\mathrm{a}}$ & $109.19^{\mathrm{c}}$ & $1.08^{\mathrm{c}}$ & $1.27^{\mathrm{a}}$ & $0.51^{\mathrm{b}}$ & $1.57^{\mathrm{b}}$ & $0.45^{\mathrm{a}}$ & $1.36^{\mathrm{a}}$ & $117.73^{\mathrm{a}}$ & $49.31^{\mathrm{c}}$ & $0.31^{\mathrm{a}}$ & $0.27^{\mathrm{a}}$ \\
\hline & S. pubescens ${ }^{*}$ & $16.08^{\mathrm{c}}$ & $4.98^{\mathrm{a}}$ & $1.65^{\mathrm{a}}$ & $0.90^{\mathrm{a}}$ & $14.44^{\mathrm{a}}$ & $12.62^{\mathrm{a}}$ & $3.14^{\mathrm{a}}$ & $122.79^{\mathrm{b}}$ & $0.86^{\mathrm{d}}$ & $1.04^{\mathrm{b}}$ & $0.58^{\mathrm{b}}$ & $2.07^{\mathrm{a}}$ & $0.34^{\mathrm{b}}$ & $0.72^{b}$ & $77.95^{\mathrm{b}}$ & $14.54^{\mathrm{d}}$ & $0.23^{b}$ & $0.17^{b}$ \\
\hline & S. torvum $1^{\#}$ & $43.35^{\mathrm{a}}$ & $2.67^{\mathrm{c}}$ & $1.12^{\mathrm{c}}$ & $0.67^{b}$ & $6.20^{\mathrm{d}}$ & $5.61^{\mathrm{c}}$ & $2.18^{\mathrm{a}}$ & $124.92^{\mathrm{b}}$ & $1.43^{\mathrm{a}}$ & $1.27^{\mathrm{a}}$ & $1.47^{\mathrm{a}}$ & $1.44^{\mathrm{b}}$ & $0.45^{\mathrm{a}}$ & $1.19^{\mathrm{a}}$ & $117.37^{\mathrm{a}}$ & $173.54^{\mathrm{a}}$ & $0.19^{c}$ & $0.11^{\mathrm{c}}$ \\
\hline & S. torvum $2^{\#}$ & $46.46^{\mathrm{a}}$ & $2.64^{\mathrm{c}}$ & $1.10^{\mathrm{c}}$ & $0.64^{b}$ & $6.11^{\mathrm{d}}$ & $5.51^{\mathrm{c}}$ & $2.50^{\mathrm{a}}$ & $123.69^{\mathrm{b}}$ & $1.42^{\mathrm{a}}$ & $1.27^{\mathrm{a}}$ & $1.49^{\mathrm{a}}$ & $1.48^{\mathrm{b}}$ & $0.47^{\mathrm{a}}$ & $1.23^{\mathrm{a}}$ & $122.97^{\mathrm{a}}$ & $262.11^{\mathrm{a}}$ & $0.19^{\mathrm{c}}$ & $0.11^{\mathrm{c}}$ \\
\hline & S. hispidum ${ }^{\#}$ & $23.75^{\mathrm{b}}$ & $4.25^{\mathrm{b}}$ & $1.33^{\mathrm{b}}$ & $0.73^{b}$ & $10.46^{\mathrm{b}}$ & $9.56^{\mathrm{b}}$ & $2.44^{\mathrm{a}}$ & $107.83^{\mathrm{c}}$ & $1.43^{\mathrm{a}}$ & $1.27^{\mathrm{a}}$ & $1.56^{\mathrm{a}}$ & $1.50^{\mathrm{b}}$ & $0.47^{\mathrm{a}}$ & $1.38^{\mathrm{a}}$ & $127.45^{\mathrm{a}}$ & $50.79^{c}$ & $0.30^{\mathrm{a}}$ & $0.30^{\mathrm{a}}$ \\
\hline & S. pubescens" & $9.51^{\mathrm{d}}$ & $5.14^{\mathrm{a}}$ & $1.68^{\mathrm{a}}$ & $0.91^{\mathrm{a}}$ & $13.18^{\mathrm{a}}$ & $11.45^{\mathrm{a}}$ & $2.89^{\mathrm{a}}$ & $122.78^{\mathrm{b}}$ & $1.02^{\mathrm{b}}$ & $1.03^{\mathrm{b}}$ & $1.46^{\mathrm{a}}$ & $2.10^{\mathrm{a}}$ & $0.35^{\mathrm{b}}$ & $0.64^{b}$ & $58.26^{\mathrm{b}}$ & $13.50^{\mathrm{d}}$ & $0.22^{\mathrm{b}}$ & $0.17^{\mathrm{b}}$ \\
\hline
\end{tabular}

Means denoted by the same letters within the column are not significantly different at $P<0.05$. NFPI= Number of flowers per inflorescence, FD= Flower diameter, PL $=$ Petal length, PW= Petal width,

$\mathrm{LSE}=$ Length of stigma exerted, $\mathrm{AL}=$ Length of anther, $\mathrm{AW}=$ Width of anther, $\mathrm{DF}=$ Days to flowering, $\mathrm{FL}=$ Fruit length, FB= Fruit breadth $(\mathrm{Fruit}$ diameter), FL/FB= Fruit length/fruit breadth ratio, $\mathrm{LS}=$

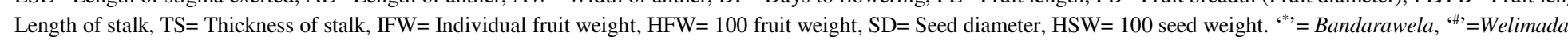


Table 5. Variability of the qualitative vegetative parameters.

\begin{tabular}{|c|c|c|c|c|c|c|c|}
\hline \multirow[b]{2}{*}{$\begin{array}{l}\text { Species/ } \\
\text { Variety }\end{array}$} & \multirow{2}{*}{$\begin{array}{c}\text { Cotyledon } \\
\text { Colour }\end{array}$} & \multirow{2}{*}{$\begin{array}{c}\text { Plant } \\
\begin{array}{c}\text { Growth } \\
\text { habit }\end{array}\end{array}$} & \multicolumn{3}{|c|}{ Leaves } & \multicolumn{2}{|c|}{ Stem } \\
\hline & & & Blade colour & $\begin{array}{l}\text { Blade tip Lobe } \\
\text { pattern }\end{array}$ & $\begin{array}{l}\text { Leaf } \\
\text { blade }\end{array}$ & $\begin{array}{c}\text { Presence of hairs and } \\
\text { prickles }\end{array}$ & Colour \\
\hline S. torvum 1 & Green & Upright & Moderate olive green & Strong & Acute & Hairs with prickles & Yellowish grey \\
\hline S. torvum 2 & Green & Upright & Moderate olive green & Strong & Acute & Hairs with prickles & Yellowish grey \\
\hline S. hispidum & Light violet & Intermediate & Greyish olive green & Strong & Acute & Hairs with prickles & Light olive grey \\
\hline S. pubescens & Light violet & Upright & Greyish olive green & Intermediate & Acute & Prickles only & Moderately olive green \\
\hline
\end{tabular}

Table 6. Variability of floral, seed and fruit characteristics.

\begin{tabular}{|c|c|c|c|c|c|c|c|c|c|c|c|c|c|c|c|}
\hline \multirow[b]{2}{*}{ 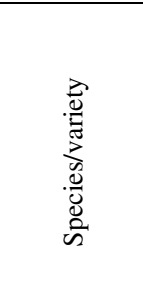 } & \multicolumn{4}{|c|}{ Flower } & \multirow[t]{2}{*}{ Seed } & \multicolumn{10}{|c|}{ Fruit } \\
\hline & 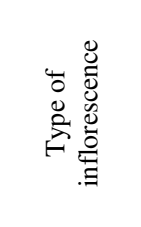 & $\begin{array}{l}\vdots \\
0 \\
0 \\
0 \\
\tilde{O} \\
\overline{0} \\
0 \\
0\end{array}$ & 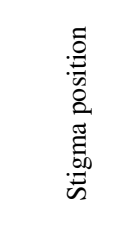 & 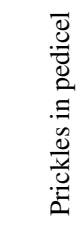 & & 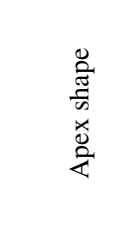 & 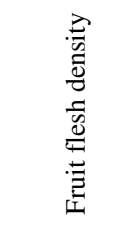 & 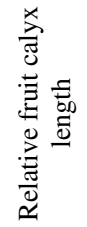 & $\begin{array}{l}\vdots \\
\frac{0}{0} \\
0 \\
\frac{0}{0} \\
0 \\
0 \\
0\end{array}$ & 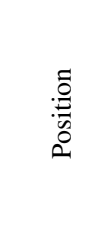 & $\frac{\overline{0}}{0}$ & $\begin{array}{l}\stackrel{\Xi}{\Xi} \\
\stackrel{\Xi}{\Xi} \\
\Xi\end{array}$ & 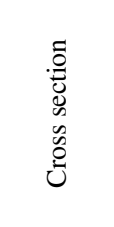 & $\begin{array}{l}\frac{0}{3} \\
\frac{\vec{J}}{0} \\
0\end{array}$ & $\frac{0}{\frac{u}{v}}$ \\
\hline S. torvum 1 & $\begin{array}{l}\text { Compound } \\
\text { dichasium }\end{array}$ & Greyish white & $\begin{array}{l}\text { Included } \\
\text { /exerted }\end{array}$ & None & $\begin{array}{l}\text { Pale } \\
\text { yellow }\end{array}$ & Rounded & $\begin{array}{l}\text { Average } \\
\text { dense }\end{array}$ & Short & $\begin{array}{l}\text { Moderate } \\
\text { yellow green }\end{array}$ & $\begin{array}{l}\text { Semi } \\
\text { erect }\end{array}$ & $\begin{array}{l}\text { Strong } \\
\text { yellow green }\end{array}$ & Straight & Circular & $\begin{array}{l}\text { No } \\
\text { grooves }\end{array}$ & None \\
\hline S. torvum 2 & $\begin{array}{l}\text { Compound } \\
\text { dichasium }\end{array}$ & Greyish white & $\begin{array}{l}\text { Included } \\
\text { /exerted }\end{array}$ & None & $\begin{array}{l}\text { Moderate } \\
\text { yellow }\end{array}$ & Rounded & $\begin{array}{l}\text { Average } \\
\text { dense }\end{array}$ & Short & $\begin{array}{l}\text { Moderate } \\
\text { yellow green }\end{array}$ & $\begin{array}{l}\text { Semi } \\
\text { erect }\end{array}$ & $\begin{array}{l}\text { Strong } \\
\text { yellow green }\end{array}$ & Straight & Circular & $\begin{array}{l}\text { No } \\
\text { grooves }\end{array}$ & None \\
\hline S. hispidum & $\begin{array}{l}\text { Compound } \\
\text { dichasium }\end{array}$ & White & exerted & None & $\begin{array}{l}\text { Moderate } \\
\text { yellow }\end{array}$ & $\begin{array}{l}\text { Protrude } \\
\text { d }\end{array}$ & Dense & Short & $\begin{array}{l}\text { Strong } \\
\text { yellow green }\end{array}$ & $\begin{array}{l}\text { Semi } \\
\text { erect }\end{array}$ & $\begin{array}{l}\text { Strong } \\
\text { yellow green }\end{array}$ & Straight & Circular & $\begin{array}{l}\text { No } \\
\text { grooves }\end{array}$ & None \\
\hline $\begin{array}{l}S . \\
\text { pubescens }\end{array}$ & $\begin{array}{l}\text { Helicoid } \\
\text { cyme }\end{array}$ & $\begin{array}{l}\text { Strong purple } \\
\text { greyish white }\end{array}$ & exerted & None & $\begin{array}{l}\text { Light } \\
\text { yellow }\end{array}$ & Rounded & $\begin{array}{l}\text { Average } \\
\text { dense }\end{array}$ & Long & $\begin{array}{l}\text { Strong } \\
\text { yellow green }\end{array}$ & $\begin{array}{l}\text { Semi } \\
\text { erect }\end{array}$ & $\begin{array}{l}\text { Strong } \\
\text { yellow green }\end{array}$ & Straight & Circular & $\begin{array}{l}\text { No } \\
\text { grooves }\end{array}$ & None \\
\hline
\end{tabular}


The stem color at the maturity stage of $S$. torvum was yellowish green, and that of the $S$. pubescens and $S$. hispidum were light olive grey and moderate olive grey respectively. Stems of the trees were moreover assessed for the presence of hairs and prickles (Plate $1 \mathrm{C}$ ). Accordingly, S. torvum and S. hispidum were found to have hairs and prickles on the stem while the stems of $S$. pubescens only possessed the prickles (Table 5). All the species possessed flowers in clusters. S. torvum and S. hispidum possessed inflorescence with compound dichasium whereas, the type of inflorescence of $S$. hispidum was helicoid cyme. The color of the corolla was also variable among the species. $S$. torvum had flowers with greyish white whereas those of the $S$. hispidum and $S$. pubescens were white and strong purple respectively. The position of the stigma in $S$. torvum was either included/exerted while those of the $S$. pubescens and S. hispidum were found to be exerted. However, none of the flowers possessed prickles in their pedicels (Plate 1 D). Moreover, the color of the seeds was found to be of variable yellows among the species (Table 6). It was also noted that most of the fruit characters were not variable among the three species revealing their less importance in discriminating of species. All the Solanum species possessed strong yellow-green, semi-erect fruits with a straight curvature, circular cross-section, no grooved locules and no prickles in fruit calyx. Nevertheless, the fruits of $S$. torvum and $S$. pubescens possessed a round apex and average dense fruit flesh while those of the $S$. hispidum possessed a protruded apex and dense fruit flesh. The relative length of the fruit calyx of $S$. torvum and $S$. hispidum was short whereas that of the $S$. pubescens was comparatively long. Furthermore, the color of the petiole at the maturity stage in $S$. torvum species was moderately yellowish green while those of the $S$. pubescens and S. hispidum were found to have a strong yellow-green (Table 6) (Plate $1 \mathrm{E}$ and F). Qualitative traits however, played a key role in differentiating the three species thus providing a better way to develop easily utilizable morphometric markers for species identification within the same genera. Although a variation was detected, it is relatively difficult to distinguish the species based on the quantitative traits, as compared to qualitative morphological traits. Our results are in conformity with the previous findings in Yousaf et al., (2010).

\section{Cluster analysis of quantitative parameters}

The dendrogram constructed considering both vegetative and reproductive characteristics showed a clear separation between three different Solanum spp. S. torvum 1 and S. torvum 2 which belong to $S$. torvum were clustered together at $79.78 \%$ similarity level. S. pubescens was highly diverse from the other varieties based on the morphological characteristics (Figure 1).

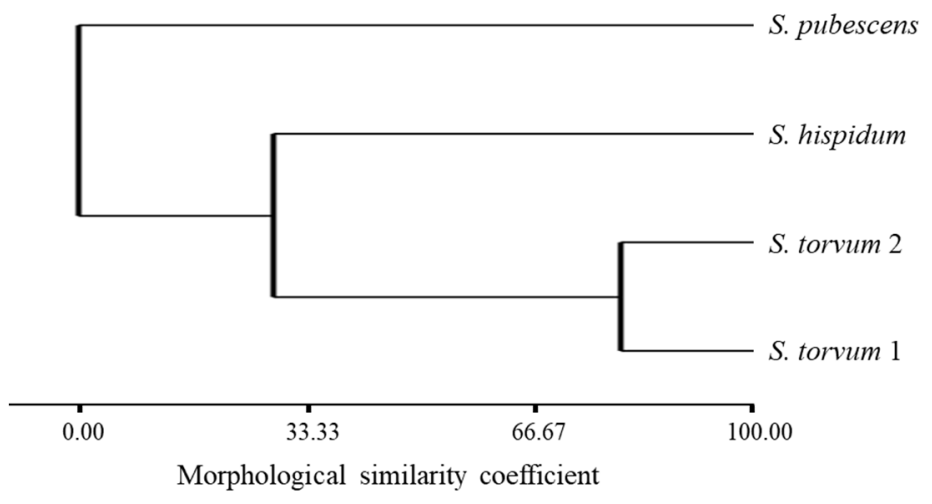

Figure 1. Dendrogram obtained for Solanum spp. based on both vegetative and reproductive characters. The $\mathrm{X}$-axis shows the level of similarity. 


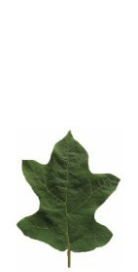

Al
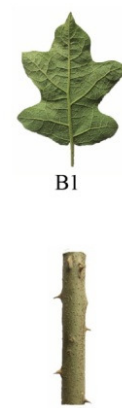

$\mathrm{Cl}$

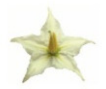

D1

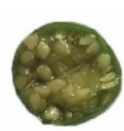

E1

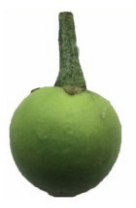

F 1

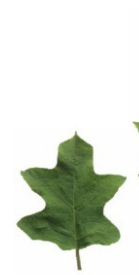

A2

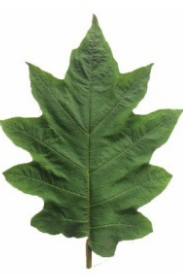

A3

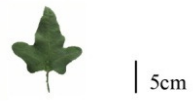

A4
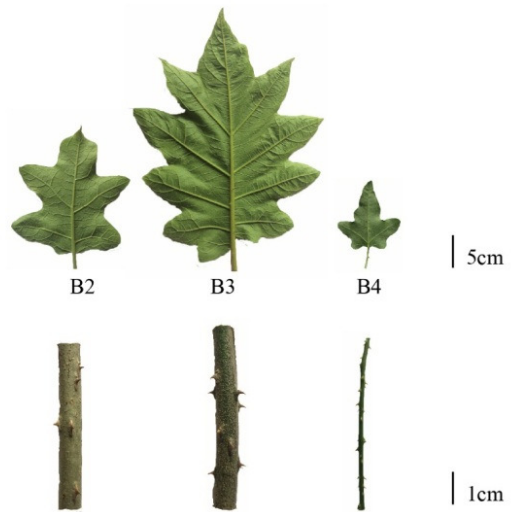

$\mathrm{C} 3$

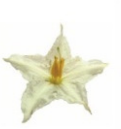

D3

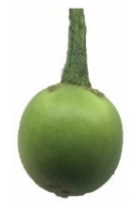

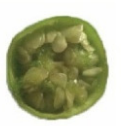

E3

F2

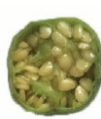

E2

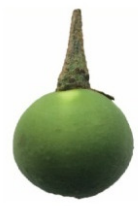

F3

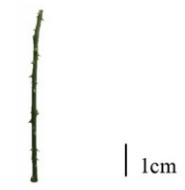

C4

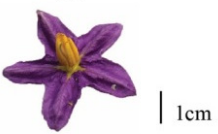

D4

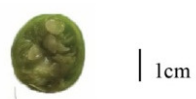

E4

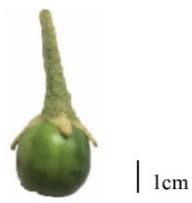

F4

Plate 1. Variability of vegetative $(\mathrm{A}, \mathrm{B}, \mathrm{C})$ and reproductive traits $(\mathrm{D}, \mathrm{E}, \mathrm{F})$ among three species of Solanum. (1: S. torvum var. Bindu; 2: S. torvum strain Landrace; 3: $S$. hispidum; 4: S. pubescens) The characteristics $A$ and $B$ represent abaxial and adaxial surface of leaf lamina, and C, D, E, F represent stem cuttings, flowers, cross sections of fruits and whole fruits, respectively. 
The PCA yielded 29 components corresponding to 29 morphometric parameters including 11 vegetative and 18 reproductive traits (Figure 2). A total variance of $98.2 \%$ was obtained collectively for the first two components of the PCA performed where PC1 and PC2 accounted for $67.8 \%$ and $30.4 \%$ respectively. The third component produced a variance of $1.9 \%$ which did not improve the outcomes of the study and all the other components were uninformative. Therefore, third and all the other components were not considered. In the PCA scatter plot, the four species/varieties were divided into three distinct groups as $S$. hispidum (black), $S$. pubescens (brown) and S. torvum (red and blue) where the S. torvum; Bindu and S. torvum; Landrace were overlapped with no distinct separation. The extensive overlap of the two $S$. torvum varieties indicates that the morphological data cannot provide discrimination between the two varieties.

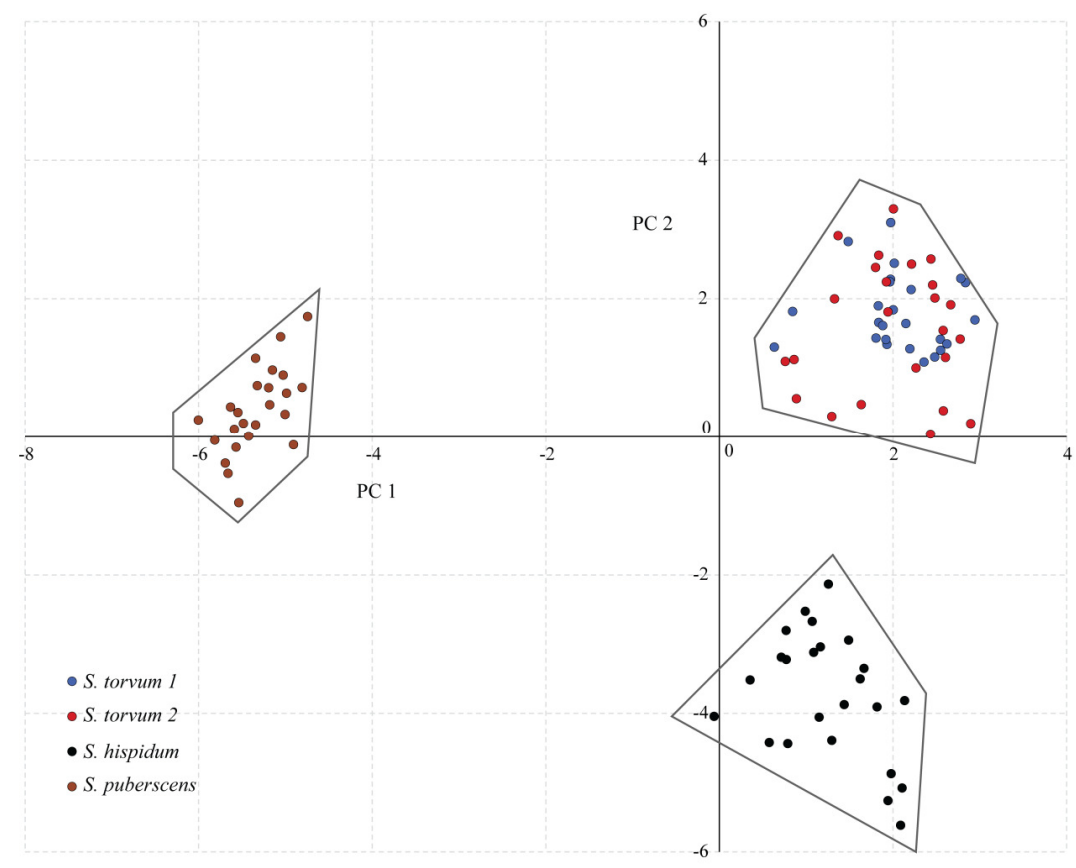

Figure 2. Scatter plot for Solanum species/varieties based on both reproductive and vegetative parameters using Minitab 17 (Minitab Inc. USA). Three distinct groups were obtained for $S$. pubescens, $S$. hispidum and $S$. torvum where the two varieties of $S$. torvum were overlapped revealing that the morphological parameters employed in the present study were not utilizable for a better discrimination between $S$. torvum varieties.

\section{Assessing the DNA length polymorphism}

The DNA bands resulted a polymorphic banding pattern for four markers namely, $\operatorname{trn} L$, $\operatorname{trn} S^{G C U}$-trn $G^{U U C}$, matK-trnT and $\operatorname{trnL} L$-trnF. Considering the aforementioned loci, S. pubescens indicated a banding pattern which is clearly distinguishable from the other vaieties indicating the genetic variability of $S$. pubescens. All the species produced monomorphic bands for atp 
B gene, atpB-rbcL, trnH-psbA and $r b c L$ (Plate 2). A total of 16 alleles were detected for eight loci. Thereby an average of two alleles per loci was identified.

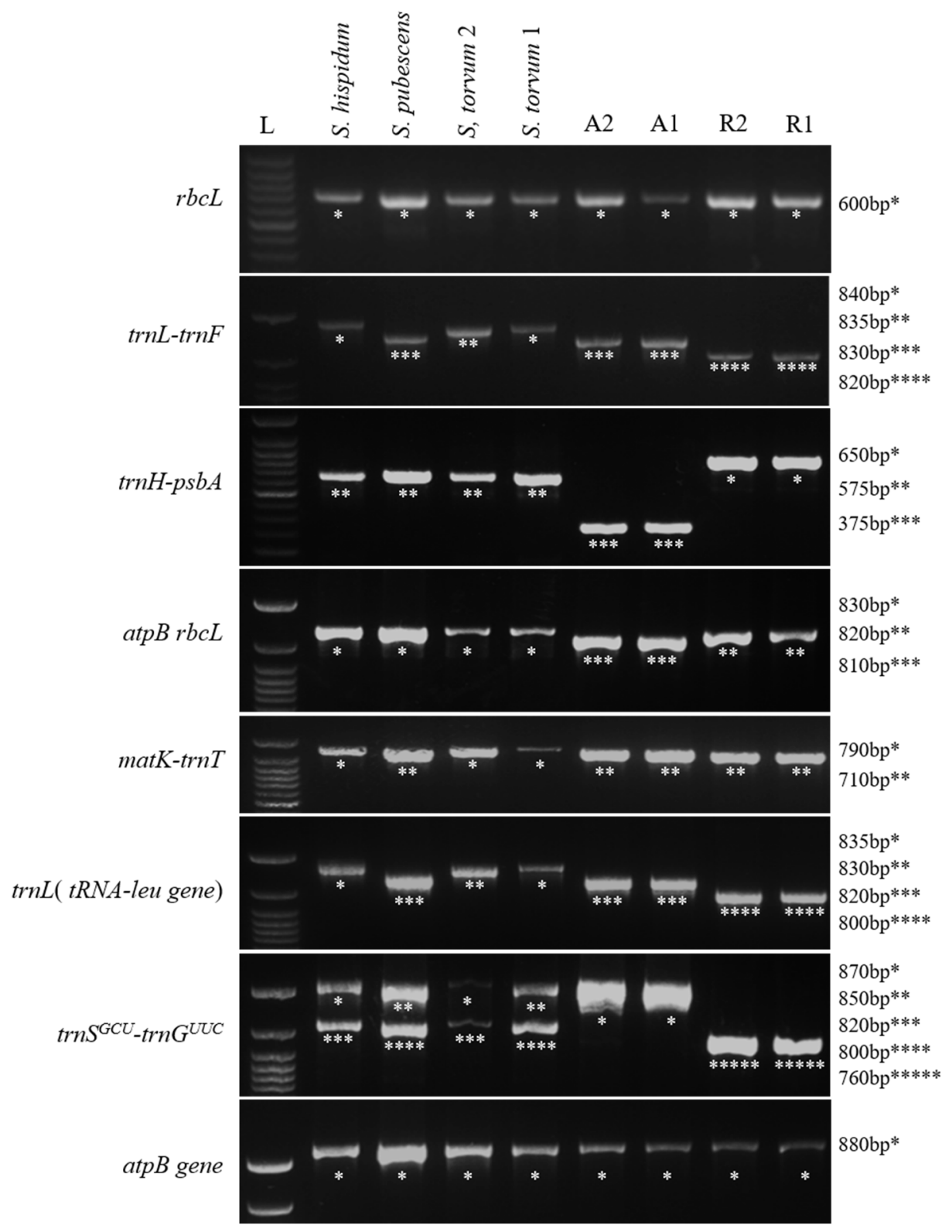

Plate 2. The polymorphic bands detected for the DNA barcoding loci (Solanum torvum; Bindu, S. torvum; Landrace, S. hispidum, S. pubescens), PCR amplified with eight markers; rbcL, trnL-trnF, trnH-psbA, atpB-rbcL, matK-trnT, trnL (tRNAleu gene), trnS $S^{G C U}-t r n G^{U U C}$ and atpB gene obtained by $2.5 \%$ agarose gel electrophoresis carried out alongside $50 \mathrm{bp}$ ladder $(\mathrm{L})$. The relative sizes of each PCR product is denoted by * mark. The increasing order of the band size is designated by increasing the number of * marks. 


\section{Assessing the DNA sequence polymorphism}

Out of the two ( $r b c L$ and $t r n L-t r n F)$ DNA barcoding markers employed in this study, there were only one SNP detected in $t r n L-t r n F$ marker for all four species/varieties. Among the individuals of nightshades, a less polymorphism was observed in $r b c L$ gene region, thus a shallow separation was obtained in the phylogeny. The 50\% majority rule consensus tree drawn in the Bayesian framework had low divergence between each sequences. The ML tree constructed for $r b c L$ maker had many polytomies and low support value (Figure 3 ) thus the employment of $r b c L$ marker would not be suitable for species/varietal discrimination. However, both the phylogenies (ML consensus tree and the Bayesian 50\% majority rule consensus tree) constructed for trnL-trnF marker had congruence in the branching pattern with a higher node support (Figure 4). The branching pattern in the $\operatorname{trnL}$-trnF phylogeny is mostly similar to previously published phylogenies where the $S$. torvum and $S$. pubescens were cladded as sister groups (Ranaweera et al., 2018; Särkinen et al., 2013). Thus the trnL-trnF could be used as candidate marker for phylogenetic studies. It is essential to combine the $t r n L$ $t r n F$ sequence data with other potential markers such as trnH-psbA and ITS to obtain a robust phylogeny. The generated sequences were submitted to GenBank under the Accession numbers MK122636-MK122643.

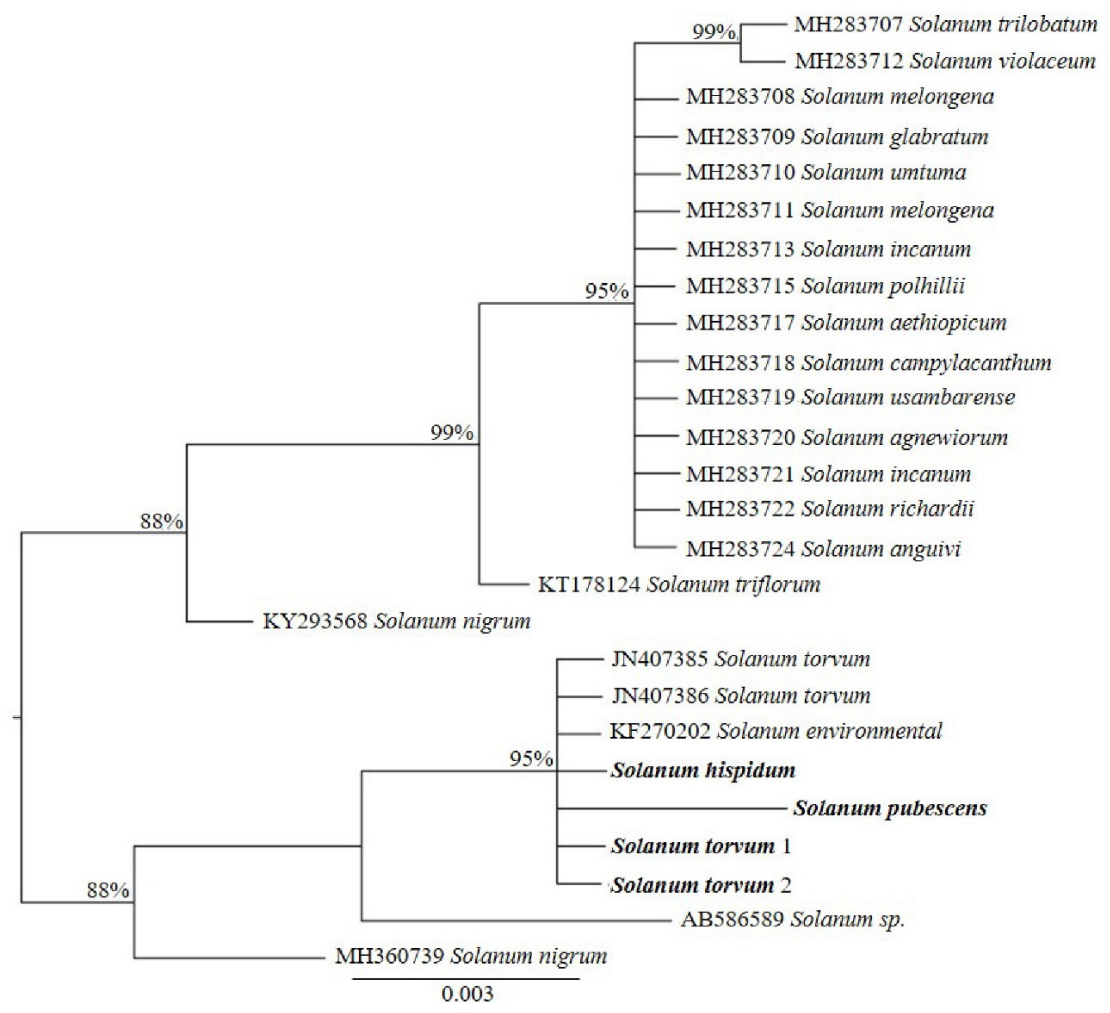

Figure 3. The mid-point rooted 50\% majority rule consensus tree drawn in the Bayesian criteria for $r b c L$ marker. The nodes having posterior probabilities (pp) $>85$ given above the node and the bootstrap values (bs) are given below the nodes. The sequences obtained in this study are given in bold letters. The scale bar represents the number of substitution per site. 


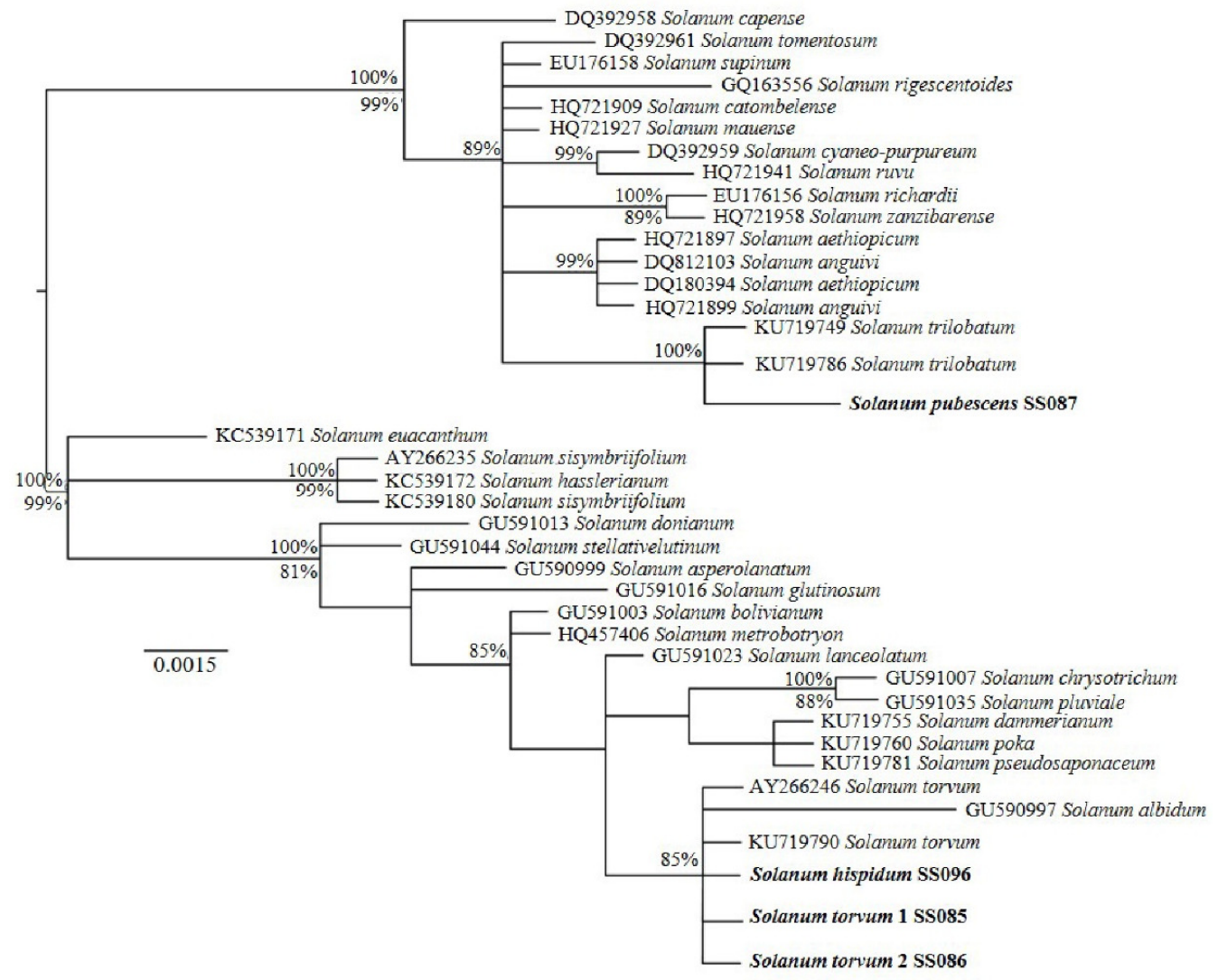

Figure 4. The 50\% majority rule consensus tree drawn in the Bayesian criteria for trnLtrn $F$ marker. The nodes having posterior probabilities Figpp) $>85$ given above the node and the bootstrap values (bs) are given below the nodes. The sequence obtained in this study are given in bold letters. The scale bar represents the number of substitution per site.

\section{CONCLUSIONS}

The analyses of morphological diversity of Solanum spp. revealed that the species identification can be successfully accomplished by considering both the vegetative and reproductive morphological parameters together. There was a less sequence polymorphism observed in $r b c L$ coding region, thus could not be used as a marker for characterization of Solanum spp. The trnL-trnF marker provides the required separation for genus Solanum and it separates S. pubescens from S. hispidum and S. torvum.

\section{ACKNOLEDGEMENT}

Regional Agriculture Research and Development Centre, Bandarawela for providing the necessary field space for establishment of plant material. 


\section{REFERENCES}

Abas, F., Lajis, N.H., Israf, D.A., Khozirah, S. and Kalsom, Y.U. (2006). Antioxidant and nitric oxide inhibition activities of selected Malay traditional vegetables. Food Chem. 95 (4), 566-573.

Akaike, H. (1974). A new look at the statistical model identification. IEEE Trans Automat. Contr. 19 (6), 716-723.

Aubriot, X., Knapp, S., Syfert, M.M., Poczai, P. and Buerki, S. (2018). Shedding new light on the origin and spread of the brinjal eggplant (Solanum melongena L.) and its wild relatives. Am. J. Bot. 105 (7), 1175-1187.

Aubriot, X., Singh, P. and Knapp, S. (2016). Tropical Asian species show that the Old World clade of 'spiny solanums'(Solanum subgenus Leptostemonum pro parte: Solanaceae) is not monophyletic. Bot. J. Linean. Soc. 181 (2), 199-223.

Aust, S.K., Ahrendsen, D.L. and Kellar, P.R. (2015). Biodiversity assessment among two Nebraska prairies: a comparison between traditional and phylogenetic diversity indices. B.D.J. (3).

Bayer, R.J., Mabberley, D.J., Morton, C., Miller, C.H., Sharma, I.K., Pfeil, B.E., Rich, S., Hitchcock, R. and Sykes, S., (2009). A molecular phylogeny of the orange subfamily (Rutaceae: Aurantioideae) using nine cpDNA sequences. Am. J. Bot. 96 (3), 668-685.

Bello, A.O., Oladipo, O.T. and Saheed, S.A. (2013). Numerical taxonomic study of some Solanum L. species (Solanaceae) using vegetative and floral morphological characters. I. J. S. 15 (3), 523-534.

Boessenkool, S., Mcglynn, G., Epp, L.S., Taylor, D., Pimentel, M., Gizaw, A., Nemomissa, S., Brochmann, C. and Popp, M. (2014). Use of ancient sedimentary DNA as a novel conservation tool for high $\square$ altitude tropical biodiversity. Conserv. Biol. 28 (2), 446-455.

Bohs, L. (2004). A chloroplast DNA phylogeny of Solanum section Lasiocarpa. Syst. Botany. 29 (1), 177-187.

Bohs, L., Weese, T., Myers, N., Lefgren, V., Thomas, N., Van Wagenen, A. and Stern, S. (2007). Zygomorphy and heteranthery in Solanum in a phylogenetic context. Acta Hortic. 745, 201.

Cavanaugh, J.E. (1997). Unifying the derivations for the Akaike and corrected Akaike information criteria. Stat. Probabil. Lett. 33 (2), 201-208.

Chah, K.F., Muko, K.N. and Oboegbulem, S.I. (2000). Antimicrobial activity of methanolic extract of Solanum torvum fruit. Fitoterapia. 71 (2), 187-189.

Chakravarty, A.K., Das, B. and Pakrashi, S.C. (1982). Solanolide, a steroid lactone sapogenin from Solanum hispidum. Phytochemistry. 21 (8), 2083-2085. 
Clain, C., Da Silva, D., Fock, I., Vaniet, S., Carmeille, A., Gousset, C., Sihachakr, D., Luisetti, J., Kodja, H. and Besse, P. (2004). RAPD genetic homogeneity and high levels of bacterial wilt tolerance in Solanum torvum Sw.(Solanaceae) accessions from Reunion Island. Plant Sci. 166 (6), 1533-1540.

Collonnier, C., Fock, I., Daunay, M.C., Servaes, A., Vedel, F., Siljak-Yakovlev, S., Souvannavong, V. and Sihachakr, D. (2003). Somatic hybrids between Solanum melongena and $S$. sisymbrifolium, as a useful source of resistance against bacterial and fungal wilts. Plant Sci. 164 (5), 849-861.

Collonnier, C., Fock, I., Kashyap, V., Rotino, G.L., Daunay, M.C., Lian, Y., Mariska, I.K., Rajam, M.V., Servaes, A., Ducreux, G. and Sihachakr, D. (2001). Applications of biotechnology in eggplant. Plant Cell Tissue Organ Cult. 65 (2), 91-107.

Department of Agriculture. (2018) [online]. [Accessed on 4.09.2018]. Available at https://www.doa.gov.lk/HORDI/.

Gandhi, G.R., Ignacimuthu, S. and Paulraj, M.G. (2011). Solanum torvum Swartz. fruit containing phenolic compounds shows antidiabetic and antioxidant effects in streptozotocin induced diabetic rats. Food Chem. Toxicol. 49 (11), 2725-2733.

González, M., Zamilpa, A., Marquina, S., Navarro, V. and Alvarez, L. (2004). Antimycotic Spirostanol Saponins from Solanum hispidum Leaves and Their Structure-Activity Relationships. J. Nat. Prod. 67 (6), 938-941.

Gousset, C., Collonnier, C., Mulya, K., Mariska, I., Rotino, G.L., Besse, P., Servaes, A. and Sihachakr, D. (2005). Solanum torvum, as a useful source of resistance against bacterial and fungal diseases for improvement of eggplant (S. melongena L.). Plant Sci. 168 (2), 319-327.

Group, C.P.W., Hollingsworth, P.M., Forrest, L.L., Spouge, J.L., Hajibabaei, M., Ratnasingham, S., van der Bank, M., Chase, M.W., Cowan, R.S., Erickson, D.L. and Fazekas, A.J. (2009). A DNA barcode for land plants. Proc. Natl. Acad. Sci. 106 (31), 12794-12797.

Hoot, S.B. and Taylor, W.C. (2001). The utility of nuclear ITS, a LEAFY homolog intron, and chloroplast $a t p B-r b c L$ spacer region data in phylogenetic analyses and species delimitation in Isoetes. Am. Fern. J. 91 (3), 166-177.

Hoot, S.B., Culham, A. and Crane, P.R. (1995). The utility of atpB gene sequences in resolving phylogenetic relationships: comparison with $r b c L$ and $18 \mathrm{~S}$ ribosomal DNA sequences in the Lardizabalaceae. Ann. Missouri Bot. Gard. 82, 194-207.

Huelsenbeck, J.P. and Ronquist, F. (2001). MrBayes: Bayesian inference of phylogeny. Bioinformatics 17, 754-755.

Jarl, C.I., Rietveld, E.M. and De Haas, J.M. (1999). Transfer of fungal tolerance through interspecific somatic hybridisation between Solanum melongena and S. torvum. Plant Cell Rep. 18 (9), 791-796. 
Jeyakumar, D.T., De Silva, U.H.A.J., Dissanayake, D.R.R.P., Chamikara, M.D.M. and Sooriyapathirana, S.D.S.S. (2016). Morpho-genetic diversity and anti-bacterial activity in root extracts of nine solanaceous species. Tropical Agricultural Research. 28, 64-87.

Kala, C.P. (2005). Ethnomedicinal botany of the Apatani in the Eastern Himalayan region of Indian. J. Ethnobiol. Ethnomed. 1, 1-8.

Kress, W.J., Erickson, D.L., Jones, F.A., Swenson, N.G. and Perez, R. (2009). Plant DNA barcodes and a community phylogeny of a tropical forest dynamics plot in Panama. Proc. Natl. Acad. Sci. 106, 18621-18626.

Kumar, S., Stecher, G. and Tamura, K. (2016). MEGA7: Molecular Evolutionary Genetics Analysis version 7.0 for bigger datasets. Mol. Biol. Evol. 33 (7), 1870-1874.

Levin, R.A., Wagner, W.L. and Hoch, P.C. (2003). Family-level relationships of Onagraceae based on chloroplast $r b c l$ and $n d h f$ data. Am. J. Bot. 90, 107-115.

Loganayaki, N., Siddhuraju, P. and Manian, S. (2010). Antioxidant activity of two traditional Indian vegetables: Solanum nigrum L. and Solanum torvum L. Food Sci. Biotechnol. 19 (1), 121-127.

Mace, E.S., Lester, R.N. and Gebhardt, C.G. (1999). AFLP analysis of genetic relationships among the cultivated eggplant, Solanum melongena L., and wild relatives (Solanaceae). Theor. Appl. Genet. 99, 626-633.

Miller, M.A., Pfeiffer, W. and Schwartz, T. (2010). Creating the CIPRES Science Gateway for inference of large phylogenetic trees. Gateway Computing Environments Workshop (GCE) 2010. 1-8 [Online]. [Accessed on 21.09.2018]. Available at http://www.ieeexplore.ieee.org/abstract document/5676129.

Porebski, S., Bailey, L.G. and Baum, B.R. (1997). Modification of a CTAB DNA extraction protocol for plants containing high polysaccharide and polyphenol components. Plant Mol. Biol. Report. 15 (1), 8-15.

Posada, D. (2008). jModelTest: phylogenetic model averaging. Mol. Biol. Evol. 25, 12531256.

Prohens, J., Gramazio, P., Plazas, M., Dempewolf, H., Kilian, B., Díez, M.J., Fita, A., Herraiz, F.J., Rodríguez-Burruezo, A., Soler, S. and Knapp, S. (2017). Introgressiomics: a new approach for using crop wild relatives in breeding for adaptation to climate change. Euphytica. 213 (7), 158.

Rambaut, A. (2014). FigTree, a graphical viewer of aphylogenetic trees. [Online]. [Accessed on 21.09.2018]. Available at http://tree. bio. ed.ac. uk/software/figtree.

Ranaweera, L.T., Hancock, J.F., Weebadde, C.K. and Sooriyapathirana, S.D.S.S. (2018). Phylogeographic and Phylogenetic analyses of selected set of Wild and naturalized Solanum spp. in Sri Lanka. Ceylon J. Sci. 47 (1), 85-93. 
Rodriguez, F.J., Oliver, J.L., Marin, A. and Medina, J.R. (1990). The general stochastic model of nucleotide substitution. J. Theor. Biol. 142 (4), 485-501.

Royal Horticultural Society (Great Britain) 2001, RHS color chart, Royal Horticultural Society, London.

Rubatzky, V.E. and Yamaguchi, M. (1997). Tomatoes, peppers, eggplants, and other solanaceous vegetables. In World Vegetables. Chapman and Hall, NewYork, New York, USA, pp.532-576.

Sang, T., Crawford, D.J. and Stuessy, T.F. (1997). Chloroplast DNA phylogeny, reticulate evolution and biogeography of Paeonia (Paeoniaceae). Am. J. Bot. 84, 1120-1136.

Sarkinen, T., Bohs, L., Olmstead, R.G. and Knapp, S. (2013). A phylogenetic framework for evolutionary study of the nightshades (Solanaceae): a dated 1000-tip tree. BMC. Evol. Biol. $13(1), 214$.

Seguí-Simarro, J.M. (2016). Androgenesis in Solanaceae. In: Germana, M. and Lambardi, M. (Eds) In Vitro Embryogenesis in Higher Plants. Methods in Molecular Biology. Humana Press, New York, NY, pp. 209-244.

Shaw, J., Lickey, E.B., Beck, J.T., Farmer, S.B., Liu, W., Miller, J., Siripun, K.C., Winder, C.T., Schilling, E.E. and Small, R.L. (2005). The tortoise and the hare II: relative utility of 21 noncoding chloroplast DNA sequences for phylogenetic analysis. Am. J. Bot. 92 (1), 142-166.

Siemonsma, J.S. and Piluek, K. (1994). PROSEA: Plant Resources of South East Asia, 8. Prosea Foundation, Bogor, Indonesia.

Stamatakis, A. (2006). RAxML-VI-HPC: maximum likelihood-based phylogenetic analyses with thousands of taxa and mixed models. Bioinformatics 22 (21), 2688-2690.

Stamatakis, A., Hoover, P. and Rougemont, J. (2008). A rapid bootstrap algorithm for the RAxML web servers. Syst. Biol. 57(5), 758-771.

Stern, S., Agra, M.D.F. and Bohs, L. (2011). Molecular delimitation of clades within New World species of the "spiny solanums" (Solanum subg. Leptostemonum). Taxon. 60 (5), 14291441.

Taberlet, P., Coissac, E., Pompanon, F., Gielly, L., Miquel, C., Valentini, A., Vermat, T., Corthier, G., Brochmann, C. and Willerslev, E. (2007). Power and limitations of the chloroplast trn L (UAA) intron for plant DNA barcoding. Nucleic Acids Res. 35 (3), 14.

Taberlet, P., Gelly, L., Pautou, G. and Bouvet, J. (1991). Universal primers for amplification of three non-coding regions of chloroplast DNA. Plant Mol. Biol. 17 (5), 1105-1109.

Tate, J.A. and Simpson, B.B. (2003). Paraphyly of Tarasa (Malvaceae) and diverse origins of the polyploid species. Syst. Botany. 28, 723-737.

Techen, N., Parveen, I., Pan, Z. and Khan, I.A. (2014). DNA barcoding of medicinal plant material for identification. Curr. Opin. Biotechnol. 25, 103-110. 
Thompson, J.D., Higgins, D.G. and Gibson, T.J. (1994). CLUSTAL W: improving the sensitivity of progressive multiple sequence alignment through sequence weighting, positionspecific gap penalties and weight matrix choice. Nucleic Acids Res. 22 (22), 4673-4680.

Tobe, H., Shinohara, W., Utami, N., Wiriadinata, H., Girmansyah, D., Oginuma, K., Azuma, H., Tokuoka, T., Kawaguchi, E., Kono, M. and Ito, M. (2010). Plant Diversity on Lombok Island, Indonesia: An Approach at Identification Using DNA Barcodes. Acta. Phytotax. Geobot. 61 (2), 93-108.

Wahlert, G.A., Chiarini, F. and Bohs, L. (2014). Phylogeny of the Carolinense clade of Solanum (Solanaceae) inferred from nuclear and plastid DNA sequences. Syst. Botany. 39 (4), 1208-1216.

Weese, T.L. and Bohs, L. (2007). A three-gene phylogeny of the genus Solanum (Solanaceae). Syst. Botany. 32 (2), 445-463.

Wicke, S. and Quandt, D. (2009). Universal primers for the amplification of the plastid trnK/matK region in land plants. In Anales del Jardín Botánico de Madrid. Consejo Superior de Investigaciones Científicas. 66, 2.

Yousaf, Z., Shinwari, Z.K. and Khan, M.A. (2010). Phenetic analysis of medicinally important species of the genus Solanum from Pakistan. Pak. J. Bot. 42 (3), 1827-1833. 